\title{
Effect of Manuring, Growth Regulators and Chemicals on Vegetative and Reproductive Characters of Seed Origin Plantation in Tamarind (Tamarindus indica)
}

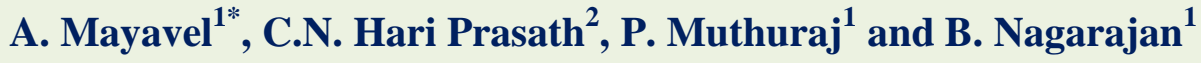 \\ ${ }^{1}$ Institute of Forest Genetics \& Tree Breeding, Forest Campus, Coimbatore - 641002 , \\ Tamil Nadu, India \\ ${ }^{2}$ Forest College and Research Institute, Tamil Nadu Agricultural University, Mettupalayam, \\ Coimbatore - 641 301, Tamil Nadu, India \\ *Corresponding author
}

\begin{tabular}{|l|}
\hline Ke y w o r d s \\
Tamarind, Growth \\
regulator and chemicals, \\
Vegetative characters, \\
$\begin{array}{l}\text { Reproductive characters, } \\
\text { Seed origin plantation }\end{array}$ \\
\hline Article Info \\
\hline $\begin{array}{l}\text { Accepted: } \\
\text { 15 September } 2018 \\
\text { Available Online: } \\
\text { 10 October } 2018\end{array}$ \\
\hline
\end{tabular}

\section{A B S T R A C T}

In order to assess the effect of manuring, growth regulators and chemicals on the vegetative and reproductive character of tamarind in seed raised plantation through soil drenching and foliar application. The treatments namely $\mathrm{T} 1$ ( $5 \mathrm{~kg}$ Organic manuring), T2 (1 kg urea +500 gm SSP + 1 kg MOP), T3 (5 kg Organic manuring + 100 gm Borax), T4

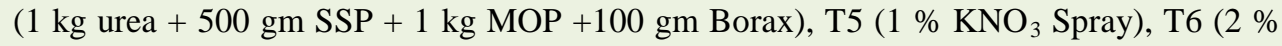
$\mathrm{KNO}_{3}$ Spray), T7 (1\% $\mathrm{K}_{2} \mathrm{HPO}_{4}$ Spray), T8 (2\% K $\mathrm{HPO}_{4}$ Spray), T9 (Cultar $2000 \mathrm{ppm}-$ Soil drenching), T10 (Cultar 3000 ppm - Soil drenching), T11 (Cultar 4000 ppm Soil drenching) and T12 (Control) were applied in tamarind plantation at Mullangaddu (Boluvampatti), Coimbatore district, Tamil Nadu, India. Vegetative and reproductive characters of tamarind were significantly improved by the application of manuring, growth regulators and chemicals. The length of terminal shoot $(22.14 \mathrm{~cm}$ and $19.47 \mathrm{~cm})$, length of auxillary shoot $(9.45$ and $8.94 \mathrm{~cm}$ ) days to first flowering (103.50 and 101.20), percentage of trees flowered (86.16\% and $86.66 \%$ ), length of inflorescence (13.26 and 5.40), no. of fruits /inflorescence (1.56 and 1.25), percentage of initial fruit set (6.409 and 7.716) and percentage fruit retention (1.228 and 1.250) were recorded maximum by the foliar application of $2 \% \mathrm{KNO}_{3}$ and soil drenching of cultar $3000 \mathrm{ppm}$. The lowest vegetative and reproductive character was observed in control (no manuring and growth regulator application). To conclude the study, the $2 \% \mathrm{KNO}_{3}$ and cultar $3000 \mathrm{ppm}$ in the tamarind tree enhanced the nutrient status in the tamarind leaves and hence it can contribute to fruit yield in tamarind plantations.

\section{Introduction}

Tamarindus indica L. is an important multipurpose tree species grown in tropical and subtropical region of the world. It is grown homestead plantation in unattended backyards, community lands, and wastelands (Gunasena and Hughes, 2000). Tamarind tree is well suited for avenue plantings in roadsides and also called as avenue tree for revenue generation. It is also integrated into various agroforestry systems to support the livelihood 
of rural communities and avoid risks associated with drought. India is the world's largest producer of tamarind products. Currently, tamarind is cultivated in an area of 0.6 million hectors with a total production of 18.54 million tones. The average productivity is 3.2 metric tons per hectors which are comparatively very low against actual potentials of 10-12 tons/Ha. It is particularly abundant in Andhra Pradesh, Karnataka, Tamil Nadu, West Bengal, Madhya Pradesh, and Bihar. Production in India is mainly concentrated in the drier southern states and the fruits are collected by villagers and sold in the open market. Tamarind is grown as a large scale plantation in the states of Andhra Pradesh, Tamil Nadu, and Karnataka.

The flower initiation has a significant influence on the time of fruit maturity and Yield. Early flowering clearly resulted in early fruit maturity. The tamarind plantation does not flower regularly year after year. Staggered flowering leads to considerable variation in fruit maturity. The induction of regular, profuse, early and uniform flowering will ensure higher yields and better returns to the farmer. The poor productivity is due to the existence of old and senile orchards, irregular bearing, poor population per unit area, nonadoption of improved technologies particularly training, pruning, irrigation management, nutrient management, use of growth regulators etc., Further, the seasonal glut in the market has been a major problem for the farmers in realizing the expected return. The large-scale Tamarind plantations made by farmers, Forest Departments of southern states have recorded low productivity due to the planting of unimproved cultivars, poor site selection non-adoption of silviculture technique. To improve the productivity of existing Tamarind orchards through enhancement of flowering and fruiting, the present study is taken upon physiological factors of tamarind orchards.

\section{Materials and Methods}

The study was carried out in the Mullangaddu (Boluvampatti), Coimbatore district, Tamil Nadu, India. The plant material consisted of tamarind trees, planted in 1990 with the spacing of $5 \times 5 \mathrm{~m}$ were employed for increasing the morphological and reproductive characters of flowering through the treatment of manuring, growth regulators and chemical application. The experiment was initiated during the month of January 2013 and observations were recorded up to March 2014. Experiments were laid out in Randomized Block Design with twelve treatments. The trees were selected on the basis of uniform vigor and development. The manure, growth regulator and chemicals sprayed are $\mathrm{T} 1(5 \mathrm{~kg}$ Organic manuring), T2 (1 kg urea +500 gm $\mathrm{SSP}+1 \mathrm{~kg} \mathrm{MOP}), \mathrm{T} 3$ (5 kg Organic manuring +100 gm Borax), T4 (1 kg urea +500 gm $\mathrm{SSP}+1 \mathrm{~kg} \mathrm{MOP}+100$ gm Borax), T5 (1\% $\mathrm{KNO}_{3}$ Spray), T6 (2\% $\mathrm{KNO}_{3}$ Spray), T7 (1\% $\mathrm{K}_{2} \mathrm{HPO}_{4}$ Spray), T8 (2\% $\mathrm{K}_{2} \mathrm{HPO}_{4}$ Spray), T9 (Cultar 2000 ppm - Soil drenching), T10 (Cultar 3000 ppm - Soil drenching), T11 (Cultar 4000 ppm Soil drenching) and T12 (Control). Foliar spray of chemicals as per the treatment schedule as given in the morning hours (between 7.00 am and 11.30 am hrs) using rocker sprayer. The total spray volume of 10 liters was used for foliar application per tree to get complete and uniform wetting.

The analysis in the manuring, growth regulators and chemical applied plantation is vegetative characters (Length of terminal shoot and Length of auxillary shoot) and reproductive characters (Days to first flowering, Percentage of tree flowered, Number of inflorescence per meter square, Length of inflorescence, Number of flowers per inflorescence, Number of fruits per inflorescence, Fruit retention at harvest and Fruit set percentage). The data obtained were subjected for statistical analysis to evaluate the 
possible relationship between the different parameters by Panse et al., (1995).

\section{Results and Discussion}

Tamarind trees were subjected to soil drenching and foliar treatments (T1 to T12) and evaluated for variations in their vegetative and reproductive traits in seedling raised tamarind plantation. The growth response of both terminal and auxillary shoot length were included for vegetative trait evaluation. The reproductive traits were grouped into flowering characteristics and fruiting characteristics. In this, the flowering characteristics included the no. of days to first flowering, percent of trees flowered, length of inflorescence, no. of flowers/inflorescence, no. of fruits/inflorescence and percentage of initial fruit set. The results are presented here

\section{Vegetative character}

Singh (1960) reported that studying the differentiation and development of flower buds in trees postulated that flower initiation in flowering trees was governed by the 'on and 'off-year conditions of the tree rather than the age, length and maturity conditions of shoots. The maximum length of $24.96 \mathrm{~cm}$ was observed in trees that were supplied with $1 \mathrm{~kg}$ urea $+500 \mathrm{~g} \mathrm{SSP}+1 \mathrm{~kg}$ MOP (IM) and the minimum of $13.21 \mathrm{~cm}$ was recorded in control, which not higher than any of the treatments that were tried (Table 1). A positive relation between percent flower bearing capacity and growth regulators was reported by Majumdar and Mukheijee (1961). The response of auxiliary shoot length in tamarind seedling orchard differed with treatments (Table 1) with the maximum length of 10.24 $\mathrm{cm}$ for trees treated with T4 (1 kg urea $+500 \mathrm{~g}$ $\mathrm{SSP}+1 \mathrm{~kg} \mathrm{MOP}$ ) and the minimum auxiliary shoot length of $7.12 \mathrm{~cm}$ was observed in T12 (Control). Regarding the effects of growth retardants on flowering and fruiting of Langra mangoes, Maiti and Sen (1968) reported the beneficial effects of $\mathrm{B}-\mathrm{Nine}$ and $\mathrm{CCC}$ on flower induction.

\section{Reproductive character}

Bhagwan et al., (2014) found that there was a significant difference among flower enhancing plant growth regulators with respect to time taken for panicle initiation after spraying of plant growth regulators. The application of manuring, growth regulators and chemicals imposed on seedling orchards substantially decreased the no. of days in preparing trees to initiate flowering (Table 2). The no. of days to first flowering ranged from 101.20 - 135.24. The process of T10 - Cultar 3000 ppm (Drenching) reduced the no. of days to 101.20 for first flowering and maximum length of flowering was recorded in control treatment (135.24).

The percentage of flowering trees varied significantly with varied treatments which ranged from 13.33 per cent to 86.66 per cent (Table 2). The maximum percentage of flowering trees $(86.66 \%)$ was observed in trees administered with $2 \% \mathrm{KNO}_{3}$ spray (T6) and cultar $3000 \mathrm{ppm}$ drenching (T10) while those treated with $5 \mathrm{~kg}$ organic manure and 5 $\mathrm{kg}$ organic manure $+100 \mathrm{~g}$ Borax showed minimum flowering (16.60 \%), whereas control exhibited only 13.33 per cent of flowering. The no. of inflorescences/sq.m varied significantly for different treatments and ranged from 6.96 to 72.33 (Table 2) in seed origin tamarind plantation. Trees subjected to cultar $3000 \mathrm{ppm}$ drenching had more inflorescences/sq.m (72.33) followed by 70.84 in those sprayed with $2 \% \mathrm{KNO}_{3}$. Trees that were supplied with $5 \mathrm{~kg}$ of organic manure (T1) had a very less no. of inflorescence 12.09/sq.m. The inflorescence length in tamarind seedling orchards varied from 4.50 (Control) to $13.26 \mathrm{~cm}\left(2 \% \mathrm{KNO}_{3}\right.$ Spray) for the effect of different treatments. 
Table.1 Effects of manuring, chemical and growth regulator treatments on vegetative characters of seedling origin tamarind plantation in Mullangaddu, Coimbatore, Western Tamil Nadu, India

\begin{tabular}{|c|c|c|c|}
\hline $\begin{array}{l}\text { Treatment } \\
\text { No. }\end{array}$ & Treatments & $\begin{array}{l}\text { Length of Terminal } \\
\text { shoot }(\mathrm{cm})\end{array}$ & $\begin{array}{l}\text { Length of Auxiliary } \\
\text { shoot (cm) }\end{array}$ \\
\hline T1 & 5 kg Organic manuring $(\mathrm{OM})$ & 15.15 & 8.22 \\
\hline T2 & $1 \mathrm{~kg}$ urea $+500 \mathrm{gm} \mathrm{SSP}+1 \mathrm{~kg}$ MOP (IM) & 24.96 & 10.24 \\
\hline T3 & $5 \mathrm{~kg}$ Organic manuring +100 gm Borax & 15.24 & 7.65 \\
\hline T4 & $1 \mathrm{~kg}$ urea $+500 \mathrm{gm} \mathrm{SSP}+1 \mathrm{~kg} \mathrm{MOP}+100 \mathrm{gm}$ Borax & 24.15 & 9.98 \\
\hline T5 & $1 \% \mathrm{KNO}_{3}$ Spray & 21.14 & 8.76 \\
\hline T6 & $2 \% \mathrm{KNO}_{3}$ Spray & 22.14 & 9.45 \\
\hline T7 & $1 \% \mathrm{~K}_{2} \mathrm{HPO}_{4}$ Spray & 19.45 & 8.54 \\
\hline T8 & $2 \% \mathrm{~K}_{2} \mathrm{HPO}_{4}$ Spray & 19.56 & 8.26 \\
\hline T9 & Cultar 2000 ppm (Soil Drenching) & 17.14 & 8.15 \\
\hline T10 & Cultar 3000 ppm (Soil Drenching) & 19.47 & 8.94 \\
\hline T11 & Cultar 4000 ppm (Soil Drenching) & 17.45 & 8.45 \\
\hline \multirow[t]{3}{*}{ T12 } & Control & 13.21 & 7.12 \\
\hline & Mean & 18.585 & 8.424 \\
\hline & CD & 2.411 & 1.212 \\
\hline & SED & 1.191 & 0.599 \\
\hline
\end{tabular}

Table.2 Effect of manuring, chemical and growth regulator treatments on Days to first flowering, Percentage of the trees flowered, No. of inflorescence, Length of inflorescence in seed origin tamarind plantation in Mullangaddu, Coimbatore, Western Tamil Nadu, India

\begin{tabular}{|c|c|c|c|c|c|}
\hline $\begin{array}{l}\text { Treat. } \\
\text { No. }\end{array}$ & Treatments & $\begin{array}{l}\text { Days to first } \\
\text { flowering }\end{array}$ & $\begin{array}{c}\text { Percentage of } \\
\text { the trees } \\
\text { flowered }(\%)\end{array}$ & $\begin{array}{c}\text { No. of } \\
\text { inflorescence/ } \\
\text { Sq.m }\end{array}$ & $\begin{array}{l}\text { Length of } \\
\text { inflorescence } \\
\text { (cm) }\end{array}$ \\
\hline T1 & 5 kg Organic manuring & 123.21 & 16.65 & 10.32 & 6.89 \\
\hline T2 & $1 \mathrm{~kg}$ urea + 500gm SSP + $1 \mathrm{~kg}$ MOP & 131.45 & 20.21 & 17.24 & 5.96 \\
\hline T3 & $5 \mathrm{~kg}$ Organic manuring +100 gm Borax & 123.45 & 16.60 & 12.09 & 6.18 \\
\hline T4 & $\begin{array}{l}1 \mathrm{~kg} \text { urea }+500 \mathrm{gm} \mathrm{SSP}+1 \mathrm{~kg} \mathrm{MOP} \\
+100 \text { gm Borax }\end{array}$ & 121.48 & 23.32 & 26.33 & 7.25 \\
\hline T5 & $1 \% \mathrm{KNO}_{3}$ Spray & 105.20 & 73.33 & 56.24 & 10.25 \\
\hline T6 & $2 \% \mathrm{KNO}_{3}$ Spray & 103.50 & 86.66 & 70.84 & 13.26 \\
\hline $\mathrm{T7}$ & $1 \% \mathrm{~K}_{2} \mathrm{HPO}_{4}$ Spray & 112.24 & 66.66 & 43.96 & 9.54 \\
\hline T8 & $2 \% \mathrm{~K}_{2} \mathrm{HPO}_{4}$ Spray & 112.14 & 80.40 & 55.67 & 8.24 \\
\hline T9 & Cultar 2000 ppm - Soil Drenching & 110.21 & 73.33 & 64.15 & 6.96 \\
\hline T10 & Cultar $3000 \mathrm{ppm}$ - Soil Drenching & 101.20 & 86.66 & 72.33 & 5.40 \\
\hline T11 & Cultar $4000 \mathrm{ppm}$ - Soil Drenching & 109.21 & 66.66 & 56.14 & 5.20 \\
\hline T12 & Control & 135.24 & 13.33 & 6.96 & 4.50 \\
\hline \multicolumn{2}{|c|}{ Mean } & 113.71 & 43.65 & 33.50 & 6.87 \\
\hline \multicolumn{2}{|r|}{ CD } & 14.51 & 7.03 & 4.99 & 1.21 \\
\hline \multicolumn{2}{|r|}{ SED } & 7.17 & 3.74 & 2.47 & 0.51 \\
\hline
\end{tabular}


Table.3 Effect of manuring, growth regulators and chemical treatments on No. of flower/inflorescence, No. of fruits /inflorescence, Percentage of initial fruit set, Percentage fruit retention in seed origin tamarind plantation in Mullangaddu, Coimbatore,

Western Tamil Nadu, India

\begin{tabular}{|c|c|c|c|c|c|}
\hline $\begin{array}{l}\text { Treat. } \\
\text { No. }\end{array}$ & Treatments & $\begin{array}{l}\text { No. of flower/ } \\
\text { inflorescence }\end{array}$ & $\begin{array}{l}\text { No. of fruits } \\
\text { /inflorescence }\end{array}$ & $\begin{array}{l}\text { Percentage of } \\
\text { initial fruit } \\
\text { set }\end{array}$ & $\begin{array}{l}\text { Percentage } \\
\text { fruit retention }\end{array}$ \\
\hline $\mathbf{T 1}$ & 5 kg Organic manuring & 14.25 & 0.61 & 4.281 & 0.453 \\
\hline $\mathbf{T 2}$ & $\begin{array}{l}1 \mathrm{~kg} \text { urea }+500 \mathrm{gm} \mathrm{SSP} \\
+1 \mathrm{~kg} \mathrm{MOP}\end{array}$ & 13.82 & 0.70 & 5.065 & 0.502 \\
\hline T3 & $\begin{array}{l}5 \text { kg Organic manuring }+ \\
100 \text { gm Borax }\end{array}$ & 17.14 & 0.78 & 4.551 & 0.642 \\
\hline $\mathrm{T4}$ & $\begin{array}{l}1 \mathrm{~kg} \text { urea }+500 \mathrm{gm} \mathrm{SSP} \\
+1 \mathrm{~kg} \mathrm{MOP}+100 \mathrm{gm} \\
\text { Borax }\end{array}$ & 18.26 & 1.02 & 5.586 & 0.451 \\
\hline T5 & $1 \% \mathrm{KNO}_{3}$ Spray & 21.26 & 1.12 & 5.268 & 0.925 \\
\hline T6 & $2 \% \mathrm{KNO}_{3}$ Spray & 24.34 & 1.56 & 6.409 & 1.228 \\
\hline $\mathrm{T7}$ & $1 \% \mathrm{~K}_{2} \mathrm{HPO}_{4}$ Spray & 20.14 & 1.02 & 5.065 & 0.860 \\
\hline $\mathrm{T} 8$ & $2 \% \mathrm{~K}_{2} \mathrm{HPO}_{4}$ Spray & 16.16 & 1.12 & 6.931 & 0.947 \\
\hline T9 & $\begin{array}{l}\text { Cultar } 2000 \text { ppm - Soil } \\
\text { Drenching }\end{array}$ & 13.54 & 0.86 & 6.352 & 0.745 \\
\hline T10 & $\begin{array}{l}\text { Cultar } 3000 \text { ppm - Soil } \\
\text { Drenching }\end{array}$ & 16.20 & 1.25 & 7.716 & 1.250 \\
\hline T11 & $\begin{array}{l}\text { Cultar } 4000 \text { ppm - Soil } \\
\text { Drenching }\end{array}$ & 15.21 & 1.01 & 6.733 & 0.526 \\
\hline $\mathrm{T} 12$ & Control & 9.15 & 0.12 & 1.333 & 0.125 \\
\hline \multicolumn{2}{|c|}{ Mean } & 15.92 & 0.85 & 5.19 & 0.68 \\
\hline \multicolumn{2}{|r|}{ CD } & 2.08 & 0.13 & 0.68 & 0.10 \\
\hline \multicolumn{2}{|r|}{ SED } & 1.03 & 0.06 & 0.33 & 0.55 \\
\hline
\end{tabular}

There was a significant difference on the no. of flowers produced per inflorescence in seed origin tamarind plantation (Table 3). It was high (24.34) in trees sprayed with $2 \% \mathrm{KNO}_{3}$ and low (13.54) in trees subjected to Cultar 2000 ppm by using soil drenching. The control had a least no. of flowers/inflorescence (9.15). The effect of different treatment on the number of fruits per inflorescence in seed origin tamarind plantation differed significantly with the maximum number (1.56) of fruits per inflorescence was observed in trees spraying with $2 \%$ of $\mathrm{KNO}_{3}$ (T6) followed by trees treated with soil drenching of Cultar 3000 ppm (1.25) in T10 and the lowest number of fruits per inflorescence was recorded in Control (0.12). On supporting the present study, plant growth regulators treated trees leads to an increase in days taken for fruit set from panicle initiation might be beneficial for better fruit set and fruit retention in Tamarind (Ullah et al., 2012)

The initial fruit set percentage ranged from 1.333 per cent to 7.716 under various treatments with the highest initial fruit set of 7.716 per cent was observed in trees subjected to soil drenching with Cultar 3000 ppm (T10) followed by 6.931 per cent in trees sprayed with $2 \%$ $\mathrm{K}_{2} \mathrm{HPO}_{4}$ (T6) and the trees subjected to $5 \mathrm{~kg}$ Organic manuring showed poor initial fruit set 
of 4.281 per cent, Whereas, in control (T12) was very minimum with the value of 1.333 per cent. The similar phenomenon on fruit retention percentage was attained with the maximum in soil drenching with Cultar 3000 ppm (1.250) and lowest fruit retention of 0.125 per cent was attained in Control (T12).

Vegetative (Length of Terminal shoot and Length of Auxillary shoot) and reproductive character (Days to first flowering, Percentage of the trees flowered, No. of inflorescence/Sq.m, Length of inflorescence, No. of flower/ inflorescence, Percentage of initial fruit set and Percentage fruit retention) were significantly improved by the application of manuring, growth regulators and chemicals in tamarind seed raised plantation. The Length of Auxillary shoot, No. of flower/ inflorescence, Percentage of initial fruit set and Percentage fruit retention was enhanced by the foliar application of $2 \%$ $\mathrm{KNO}_{3}$ and soil drenching of cultar $3000 \mathrm{ppm}$, when compared to T12 (Control). The optimum level of vegetative and reproductive attributes is highly correlated with fruit yield. Hence, the application of manuring, growth regulator and chemicals not only improves the morphological and reproductive behaviour of tamarind, but also fruit yield.

\section{Acknowledgment}

The author wishes to thank Director General, Indian Council of Forestry Research and Education, Dehradun for financial assistance and Principal Chief Conservator of Forest, Tamil Nadu Forest Department for providing permission to carry out research experiments in Tamarind Plantation. Thanks are also due to research staff member of the Genetics and Tree Improvement Division of Institute of Forest
Genetic and Tree Breeding for their assistance when this study was carried out

\section{References}

Bhagwan, A., Vijaya Krishna and M. Rajkumar. 2014. Synergistic effects of plant growth regulators and fruit set improving chemicals on flowering, fruit set and yield of mango cv Banganpalli. National Seminar-cum-Workshop on Physiology of Flowering in Perennial Fruit Crops. Pp. 210-228.

Gunasena, H.P.M and Hughes, A. 2000. Fruits for the future - Tamarind (Tamarindus indica L.). International centre for underutilized crops, Southampton (UK) Pp.: 170.

Maiti, S.C. and P.K. Sen. 1968. Effect of growth retardants on flowering and fruiting of Langra mango. Current Science, 19: 566-567.

Majumder, P.K. and S.K. Mukherjee. 1961. Studies on variability of sex-expression in mango (Mangifera indica L.). Indian J. Horti., 18: 12-19.

Panse, V.G., P.V. Sukhatme and V.N. Amble. 1985. Statistical methods for agricultural workers (Ref. Edn.). ICAR, New Delhi.

Singh, R.N. 1960. Studies in the differentiation and development of fruit buds in mango (Mangifera indica L.). IV. Periodical changes in the chemical composition of shoots and their relation with fruit bud differentiation. Hort. Adv., 4: 48-68.

Ullah, Faizan, Asghari Bano and Asia Nosheen. 2012. Effects of plant growth regulators on growth and oil quality of canola (Brassica napus L.) under drought stress. Pak. J. Bot., 44(6): 1873-1880.

\section{How to cite this article:}

Mayavel, A., C.N. Hari Prasath, P. Muthuraj and Nagarajan, B. 2018. Effect of Manuring, Growth Regulators and Chemicals on Vegetative and Reproductive Characters of Seed Origin Plantation in Tamarind (Tamarindus indica). Int.J.Curr.Microbiol.App.Sci. 7(10): 1821-1826. doi: https://doi.org/10.20546/ijcmas.2018.710.208 